\title{
Os partidos políticos brasileiros realmente não importam?
}

\author{
Maria do Socorro Sousa Braga \\ Departamento de Ciências Sociais e do \\ Programa de Pós-Graduação em Ciência Política \\ Universidade Federal de São Carlos. \\ Jairo Pimentel Jr \\ Doutorando do Programa de Ciência Política da \\ Universidade de São Paulo
}

\begin{abstract}
Resumo: Há décadas a constatação corrente no Brasil é de que os partidos pouco importam para explicar o comportamento dos eleitores brasileiros. Entretanto, esse cenário de baixa identificação partidária contrasta com a observação de que, ao menos para as eleições presidenciais a competição eleitoral tem se estruturado em torno de duas organizações partidárias: PT e PSDB. O objetivo deste artigo é demonstrar que mesmo que os partidos de fato não estejam internalizados em termos de identidade partidária, estamos vivenciando importante movimento no sentido de uma divisão do eleitorado entre as duas principais organizações políticas em termos de simpatia partidária, redundando na estruturação de um sistema bipartidário ao nível da disputa nacional. Com base nas respostas dos entrevistados do ESEB 2002, 2006 e 2010 sobre as eleições presidências verificamos que nesses pleitos as simpatias eleitorais pelo PT e PSDB se mostraram um dos principais componentes de explicação do voto nos candidatos. Este artigo também destacou que apesar das simpatias partidárias serem uma heurística utilizada para decisão do voto entre os eleitores com maior escolaridade, foi possível observar que mesmo entre os menos escolarizados essa variável foi fundamental para explicar o voto, evidenciando que mesmo entre eleitores com menor conhecimento político, os partidos têm auxiliado na decisão do voto.
\end{abstract}

Palavras-chave: partidos políticos, comportamento eleitoral, eleições presidenciais, simpatia partidária, ESEB2010

\begin{abstract}
For decades the conventional wisdom in Brazil has been that political parties do not matter in explaining the behavior of Brazilian voters. However, this scenario of low partisan identification contrasts with the observation that, at least for presidential elections, electoral competition has been structured around two party organizations: those of the PT and PSDB. The aim of this article is to demonstrate that, even if parties are in fact not internalized in terms of party identification, we are witnessing an important division between two principal political organizations in terms of party preference, reflecting the emergence of a bipartisan system at the national level. On the basis of responses of interviewees about the presidential elections in the CSES-ESEB of 2002, 2006, and 2010, we see that in these elections the electoral affinities for the PT and PSDB are some of the principle components of an explanation of the vote. This article also emphasizes that despite the fact that party preference is more pronounced as a means of candidate selection for those with a high degree of education, it is possible to observe that even among those with less education this variable is fundamental to explain the vote, providing evidence that even for voters with less knowledge of politics, the parties are helping to structure the voting decision.
\end{abstract}

Key Words: political parties, electoral behavior, presidential elections, party sympathy, CSES-ESEB2010

OPINIÃO PÚBLICA, Campinas, vol. 17, n², Novembro, 2011, p.271-303 


\section{Introdução}

Segundo a literatura especializada, um importante componente do sistema democrático reside na conexão entre partidos e eleitores (DALTON et al, 2003; MACKUEN \& RABINOWITZ, 2003), e uma medida para avaliar a amplitude dessa vinculação foi elaborada a partir do conceito de identificação partidária. Esse conceito tornou-se o principal fator teórico na explicação do comportamento eleitoral dos americanos e um paradigma na análise da estabilidade do sistema partidário durante as décadas de 50 e 60 (DALTON et al, 2003, WATTENBERG,1982). No entanto, o declínio das taxas de partidarismo, juntamente com o aumento das tendências anti-partidárias, a partir da década de 70 nas chamadas democracias consolidadas, levaram muitos analistas a revisarem a idéia da identificação partidária como fator explicativo do voto, bem como a certo consenso acadêmico sobre a decrescente importância dos laços entre partidos e eleitores nessas democracias (DALTON et al, 2003; DALTON \& WATTENBERG, 2000; WEBB et al, 2002; GUNTHER et al, 2002; DIAMOND \& GUNTHER, 2001).

A queda nas identificações partidárias e o aumento dos sentimentos antipartidários não parecem ser fenômenos restritos às democracias industriais avançadas, pois têm sido observados também em democracias recentes. Esses comportamentos vêm ocorrendo tanto no sul da Europa, quanto no leste europeu pós-soviético (MILLER \& KLOBUCAR, 2000) e América latina (LINZ, 2002; SAÉZ \& FREDEINBERG, 2002, ANGEL, 2003).

No Brasil, parte da literatura especializada aponta para o baixo conhecimento das lideranças, para políticos apartidários, forte aversão às legendas e baixa identificação com os partidos políticos. As taxas de identificação partidária que se encontravam em $64 \%$ no final do período democrático de 1945.64 (LAVAREDA, 1999), e em 70\% durante o bipartidarismo imposto pelo regime civilmilitar (SANTOS, 1978), tiveram uma média de $46 \%$ durante o período de 1989 . 2002 (KINZO E CARREIRÃO, 2004). As razões apontadas para esse baixo índice na atual experiência democrática são de basicamente três tipos: 1) o sistema eleitoral proporcional (MAINWARING, 1995; LAVAREDA, 1999; KINZO, 2004), 2) o baixo nível cognitivo dos eleitores (MOISÉS, 1992; MÔNICA CASTRO, 1994; KINZO E CARREIRÃO, 2004, KINZO, 2005) e 3) a cultura política do populismo (SINGER, 1990; MENEGUELLO, 1994).

De maneira geral, portanto, a constatação corrente é a de que os partidos pouco importam para explicar o comportamento dos eleitores brasileiros. Entretanto, esse cenário atual de baixa identificação partidária contrasta com a observação de que, ao menos para as eleições presidenciais, a competição eleitoral 
tem se estruturado em torno de duas organizações partidárias: PT e PSDB. Diante dessa evidência, o objetivo deste artigo é demonstrar que mesmo que os partidos de fato não estejam internalizados em termos de identidade partidária, podemos observar que está em marcha no Brasil, ao menos no que concerne à estruturação do voto para presidente, uma divisão do eleitorado entre as duas principais organizações políticas em termos de simpatia partidária.

Argumentamos que o partidarismo é um forte componente para a decisão eleitoral para a disputa presidencial brasileira, podendo ser mensurado através das simpatias partidárias dos eleitores. Essas simpatias são subprodutos do histórico de disputas e da implementação de projetos políticos dos partidos. Dessa forma, mesmo aqueles eleitores que não sabem se preferem determinada linha partidária, seja pela distância e aversão que possuem em relação à política; seja pelo baixo conhecimento cognitivo acerca das legendas, a convivência com elas marca subjetivamente suas preferências ano após ano, eleição após eleição, estabelecendo inclinações que fomentam e enquadram a realidade político-eleitoral. Por outro lado, governos bem sucedidos em suas administrações também são cruciais para a formação de percepções positivas quanto à capacidade dos partidos representarem os anseios da sociedade, redundando em agentes eficientes na avaliação dos eleitores. As reeleições do PSDB (1998) e do PT (2006), e em seguida, a eleição do sucessor petista em 2010, são evidências nesse sentido.

Analisando dados das eleições de 2002, 2006 e 2010, esse artigo busca demonstrar dois aspectos referentes ao impacto das simpatias partidárias na decisão do voto nas eleições presidenciais brasileiras: primeiro, que os partidos ganharam maior importância em termos de simpatia em 2010 em relação às eleições de 2002 e, principalmente, 2006 (quando refletiram resultados de escândalos políticos). Segundo, que em todas essas eleições estudadas, as simpatias eleitorais pelo PT e PSDB se mostraram um dos principais componentes de explicação do voto nos candidatos e, por fim, esse artigo demonstra que apesar das simpatias partidárias serem uma heurística utilizada para decisão do voto entre os eleitores com maior escolaridade, é possível observar que, mesmo entre os menos escolarizados, esse elemento foi fundamental para explicar o voto, demonstrando que mesmo entre eleitores com menor conhecimento político, os partidos têm auxiliado na decisão do voto.

Para verificar nosso argumento, na seção seguinte revisamos os estudos referentes ao comportamento político do eleitor brasileiro. Em seguida, na terceira seção, verificamos qual é o grau de conhecimento, o nível de preferência partidária e o grau de simpatia dos eleitores pelos partidos em foco nas últimas três eleições, tratando da avaliar em que medida essas simpatias são fatores importantes para a 
tomada de decisão do voto, vis a vis outras variáveis consideradas relevantes pela literatura sobre o comportamento eleitoral. Na quarta seção tecemos as considerações finais.

\section{Comportamento político do eleitor e percepções sobre os partidos contemporâneos: interpretações e novas questões sobre o caso brasileiro}

É bastante considerável o volume da literatura que busca avaliar a capacidade dos partidos brasileiros de estruturar a competição político-eleitoral na atual quadra democrática. A maioria desses estudos defende que os partidos estão pouco enraizados na sociedade, limitados a uma minoria dos eleitores com maior escolaridade e envolvimento político, mitigando dessa forma, a eficiência dessa variável explicar os resultados finais dos pleitos (BALBACHVESKY, 1992; CASTRO, 1994; CARREIRÃO E KINZO, 2004; KINZO, 2005).

Boa parte desses trabalhos utiliza medidas empíricas de surveys baseados no conceito de identificação partidária, tal como formulado pela escola de Michigan (CAMPBEL et al. 1960). Tradicionalmente, nos surveys brasileiros é perguntado para os entrevistados responderem de forma espontânea se possuem algum partido de preferência. Os resultados desse tipo de medida têm sido níveis de identificação partidária com pouco menos da metade dos eleitores declarando algum partido de preferência (CARREIRÃO E KINZO, 2004; KINZO, 2005).

Todavia, esses índices de identificação partidária na jovem democracia brasileira, e considerados relativamente baixos por essa literatura, não são totalmente desalentadores. Comparado a outros países, o Brasil se encontra em um patamar não muito diferente, mesmo quando o aproximamos das chamadas democracias consolidadas, tal como pode ser observado na Tabela 1, reproduzida do artigo de Dalton e Weldon (2007).

Em relação às novas democracias, advindas da terceira onda de democratização ${ }^{1}$, o Brasil se sobressai em relação a países da América do Sul, como por exemplo, Chile e Peru, e a nações da Europa Oriental, como Eslovênia, Lituânia, Bulgária e Polônia. O Brasil encontra-se ainda em um patamar muito próximo ao do México e de Portugal. Observarmos também que em relação à Ásia, - Brasil está em melhores condições do que Tailândia e Taiwan. Em relação às democracias consolidadas, o Brasil se posiciona em níveis próximos aos

\footnotetext{
${ }^{1}$ Conceito de Huntington (1994), referindo-se ao processo de democratização pós-1974, que tem como marco a Revolução dos Cravos que derrubou a ditadura de Salazar em Portugal. Esse processo se estendeu para a América Latina entre as décadas de 70 e 80 e para o leste europeu no final dos anos 90.
} 
BRAGA, M. S. S. e PIMENTEL, J. Jr. Os partidos políticos brasileiros realmente não...

encontrados na Grã-Bretanha, Dinamarca, Noruega, Suécia, Finlândia e Irlanda, e ainda possui nível superior ao Japão, Coréia, Alemanha, Suíça, Bélgica e Holanda. Aparecem com níveis um pouco superiores, mas dentro de uma margem estreita, Islândia e Hungria. Mesmo a França e os EUA, não apresentam níveis muito maiores que os do Brasil.

Esses dados evidenciam que a conexão entre partidos e eleitores no Brasil, relativamente a outros contextos, não comporta a visão tão pessimista de grande parte dos estudiosos. Pelo contrário, do que pode ser apreendido dos dados, o Brasil se encontra dentro de uma média mundial, com patamar não muito distante das democracias avançadas, que possui média de $54 \%$ de declaração de identificação, enquanto as novas democracias possuem uma média de $37 \%$.

Tabela 1

Identificação partidária comparada

\begin{tabular}{|c|c|c|}
\hline & $1996-2000$ & 2000-05 \\
\hline Austrália & 83,5 & 83,9 \\
\hline Ucrânia & 70,5 & - \\
\hline Israel & 64,2 & 62,4 \\
\hline Estados Unidos & 57 & 56,1 \\
\hline Nova Zelândia & 56,3 & 55,7 \\
\hline Rússia & 56,1 & - \\
\hline França & - & 55,8 \\
\hline Polônia & 53,7 & 41,8 \\
\hline Suécia & 53,1 & 48,8 \\
\hline Noruega & 52,9 & 41,3 \\
\hline Canadá & 52,1 & - \\
\hline Portugal & 51,8 & 51,8 \\
\hline Islândia & 51,6 & 54,2 \\
\hline Dinamarca & 51,4 & 50 \\
\hline Brasil & - & 49,4 \\
\hline Grã-Bretanha & 48,8 & 44,9 \\
\hline República Tcheca & 48,8 & 63,7 \\
\hline México & 48,2 & 51,9 \\
\hline
\end{tabular}


OPINIÃO PÚBLICA, Campinas, vol. 17, no 2, Novembro, 2011, p.271-303

\begin{tabular}{|c|c|c|}
\hline Romênia & 47,1 & - \\
\hline Finlândia & - & 46,6 \\
\hline Espanha & 42,8 & 61,3 \\
\hline Bulgária & - & 42,7 \\
\hline Japão & 37,5 & - \\
\hline Alemanha & 37,4 & 37,2 \\
\hline Suíça & 36,7 & 42,5 \\
\hline Bélgica & - & 36,1 \\
\hline Hungria & 35,8 & 52,6 \\
\hline Lituânia & 34,6 & - \\
\hline Taiwan & 33,8 & 42,8 \\
\hline Holanda & 27,9 & - \\
\hline Irlanda & - & 27,7 \\
\hline Coréia do Sul & 27,3 & 40 \\
\hline Peru & 22,8 & - \\
\hline Eslovênia & 21,7 & . \\
\hline Tailândia & 21,5 & 17,7 \\
\hline Chile & 20,7 & - \\
\hline Bielo-Rússia & 11,7 & . \\
\hline Hong Kong & 7,9 & 28,1 \\
\hline Média* & 42,7 & 47,7 \\
\hline
\end{tabular}

1 Fonte: Comparative Study of Electoral Systems, Módulos I e II. Dados com peso (missing data não foram incluídos no cálculo dos percentuais).

Perguntas utilizadas nos surveys: Do you usually think of yourself as close to any particular political party? Which party is that?

*Adendo dos autores deste artigo, ausente da tabela original de Dalton e Weldon (2007)

Vale ressaltar que a média de identificação partidária nas democracias consolidadas vem diminuindo gradativamente nas ultimas décadas (DALTON et al, 2003), em um processo de escala global que também atinge as novas democracias (DALTON E WELDON, 2007), sobretudo em função do impacto crescente das mídias de massa e da centralização das campanhas nos candidatos, reduzindo dessa forma o papel ocupado pelos partidos no passado, aumentando os sentimentos anti-partidários e a desconfiança dos partidos na opinião pública. Nesse sentido, tal como ressalta Lavareda (1999), em um contexto generalizado como esse, de 
decrescente importância dos partidos, é bem provável não encontrarmos no futuro do Brasil níveis de identificação partidária parecidos aos existentes na experiência democrática de 1945-64, quando esse número chegou a $64 \%$ e também se equiparava aos índices encontrados nas democracias consolidadas à época.

Entretanto, é importante salientar que o partido que mais contribui para que a identificação partidária no Brasil alcance esse patamar é o PT, cujos níveis de preferência encontram-se relativamente altos, alcançando acima de $20 \%$ a partir da última década (KINZO E CARREIRÃO, 2004). A razão para isso recai sobre sua organização partidária. Tido como único partido de massas do Brasil, o PT soube se colocar junto aos movimentos sociais, integrando-se no eleitorado como um partido de esquerda e de oposição, tratando de fixar uma imagem robusta e conjunta dos seus políticos, cativando, com o passar do tempo, uma grande quantidade de eleitores (KINZO, 2005; SAMUELS, 2004). Outra possível razão para esse vínculo do PT com o eleitorado é o uso estratégico que os seus candidatos fazem do horário eleitoral gratuito. Em comparação com os demais partidos, o PT utiliza muito mais o seu símbolo partidário, e os discursos dos candidatos dão maior ênfase à questão partidária. Mesmo centradas na figura e imagem dos políticos, as campanhas dos candidatos do PT, em todos os níveis e cargos, possuem um discurso partidário que os demais partidos não fazem questão de salientar (DIAS, 2005, 2011).

A chegada à Presidência da República em 2002 fez o PT mudar sua postura, passando a moderar seu discurso e a adotar medidas pragmáticas a despeito de outras que defendia no passado. Somado a isso, vieram escândalos de corrupção envolvendo a legenda ${ }^{2}$, fazendo que o partido perdesse adeptos, sobretudo entre os mais escolarizados (VEIGA, 2007; SAMUELS E ZUCCO, 2010). Entretanto, sua marca, partidária manteve a força e alcançou forte aderência no eleitorado mesmo apos esses escândalos, tal como mostram os dados subseqüentes das pesquisas do ESEB.

Nas três pesquisas de survey do ESEB (2002, 2006 e 2010) foram realizadas duas questões similares em relação à preferência partidária, com o intuito de mensurar os níveis de partidarismo do brasileiro. Uma dessas questões tratava de analisar se os eleitores se sentiam representados por algum dos partidos

\footnotetext{
${ }^{2}$ Nesse período o PT foi marcado por três escândalos políticos: o primeiro deles foi a quebra de sigilo bancário do caseiro Francenildo Costa, que levou a queda do ministro da Fazenda, Antonio Palloci. O segundo ficou conhecido como mensalão, um esquema de pagamento de propinas a deputados da base aliada para a aprovação de projetos de interesse do governo, através do desvio de recursos públicos de estatais. Já o terceiro, ficou conhecido como dossiêgate, a tentativa frustrada pela polícia federal de compra, por pessoas ligadas ao PT, de um dossiê que supostamente teria elementos que comprovariam o envolvimento do candidato do PSDB ao governo do Estado de São Paulo em 2006, José Serra, em esquemas de corrupção.
} 
do sistema político brasileiro e, a segunda, se havia algum partido que os eleitores gostavam, ambas com respostas espontâneas (isto é, sem qualquer tipo de estimulo) por parte dos entrevistados. Os resultados obtidos por essas medidas não diferem muito dos resultados alcançados pela medida de preferência partidária tradicionalmente utilizada, ou seja, identificou-se um baixo índice de respostas, com a minoria de eleitores expressando partidarismo e o PT obtendo níveis satisfatórios de predileção, com níveis de citação muito acima das demais legendas.

Nas tabelas seguintes é possível observar as respostas a essas medidas ${ }^{3}$. Na Tabela 2 observamos que em todos os anos os estudos demonstraram haver uma minoria de eleitores que declara se sentir representado por um dos partidos brasileiros. O índice de resposta em 2006 é o menor da série, provável decorrência dos escândalos políticos do chamado mensalão durante o ano de 2005, que mitigou a confiança dos eleitores em relação aos partidos, sobretudo o PT, tendo levado a uma completa indiferenciação das legendas no eleitorado (PAIVA, BRAGA E PIMENTEL JR., 2007). Além disso, o número de eleitores que declararam gostar de uma das agremiações é de 48\% em 2002 e 2010, sendo que em 2006, há uma queda acentuada no gosto dos eleitores pelos partidos, resultado, também, das mesmas razões que fizeram os eleitores se sentirem menos representados.

Em suma, a tabela demonstra que os níveis de preferência partidária (entendida como gosto por algum partido) e de representação dos partidos em 2010 parecem ter sido restabelecidos aos níveis encontrados em 2002, ou seja, anteriormente aos eventos políticos que fizeram os partidos caírem em descrédito no contexto do ano de 2006. De maneira geral as informações da Tabela 2 reforçam a compreensão de que para quase metade dos eleitores brasileiros os partidos fazem algum sentido, seja do ponto de vista da representação de idéias, seja pelos sentimentos a eles direcionados.

\footnotetext{
3 As perguntas utilizadas para medir o partidarismo foram as seguintes:

De um modo geral, existe algum partido político que o(a) sr(a) goste? (ESPONTÂNEA E ÚNICA)

Existe algum partido político que representa a maneira como o(a) sr(a) pensa?
} 
BRAGA, M. S. S. e PIMENTEL, J. Jr. Os partidos políticos brasileiros realmente não...

Tabela 2

Representação e gosto partidário

$\%$

\begin{tabular}{|l|c|c|c|c|c|c|c|}
\hline \multirow{2}{*}{} & \multicolumn{3}{|c|}{ Representa } & \multicolumn{3}{c|}{ Gosta } \\
\cline { 2 - 8 } & $\mathbf{2 0 0 2}$ & $\mathbf{2 0 0 6}$ & $\mathbf{2 0 1 0}$ & $\mathbf{2 0 0 2}$ & $\mathbf{2 0 0 6}$ & $\mathbf{2 0 1 0}$ \\
\hline Não & 56 & 64 & 58 & 50 & 64 & 52 \\
\hline Sim & 39 & 33 & 39 & 48 & 33 & 48 \\
\hline NS/NR & 5 & 3 & 3 & 2 & 3 & 1 \\
\hline
\end{tabular}

Fonte: ESEB 2002, 2006 e 2010

Já a Tabela 3 mostra quais partidos os eleitores acreditam que os representem e de quais eles gostam ${ }^{4}$. O primeiro dado a observar, tanto para uma variável, quanto para outra, é o numero de respostas para a legenda PT em comparação com as demais legendas que, somadas, não atingem o mesmo nível em qualquer ano pesquisado e em qualquer dessas duas perguntas. Vale destacar também o restabelecimento das legendas em nível de citação semelhantes ao ano de 2002, com o PSDB e PT obtendo uma fatia um pouco mais robusta (mas dentro da margem de erro) em relação ao primeiro ano de estudo dessa série. O PMDB, por outro lado, teve oscilação negativa em relação a 2002. Outro destaque na rodada de pesquisa de 2010 é o aparecimento do PV com 4\% de citações tanto na questão da representação, quanto na questão de gosto partidário, muito provavelmente impulsionado pela candidatura de Marina Silva à presidência, que Ihe rendeu cerca de $19 \%$ dos votos válidos no primeiro turno daquela eleição.

4 Perguntas utilizadas para mensurar isso foram:

Qual o partido que melhor representa a maneira como o(a) sr(a) pensa?(ESPONTÂNEA E ÚNICA)

Qual partido o(a) sr(a) gosta? Mais algum? Mais algum? (ESPONTÂNEA E MÚLTIPLA) 
Tabela 3

Representação e gosto por partidos específicos \%

\begin{tabular}{|l|c|c|c|c|c|c|c|}
\hline & \multicolumn{3}{|c|}{ Representa } & \multicolumn{3}{c|}{ Gosta } \\
\cline { 2 - 8 } & $\mathbf{2 0 0 2}$ & $\mathbf{2 0 0 6}$ & $\mathbf{2 0 1 0}$ & $\mathbf{2 0 0 2}$ & $\mathbf{2 0 0 6}$ & $\mathbf{2 0 1 0}$ \\
\hline PT & 23 & 18 & 24 & 26 & 22 & 28 \\
\hline PSDB & 4 & 4 & 6 & 5 & 4 & 8 \\
\hline PMDB & 4 & 4 & 3 & 7 & 3 & 5 \\
\hline PV & - & - & 4 & & 0 & 1 & 4 \\
\hline PFL/DEM & 2 & - & 1 & 3 & 1 & 1 \\
\hline Outros com menos de 1\% & 2 & 3 & 2 & & 2 & 1 & 3 \\
\hline NS/NR/NA & 4 & 5 & 1 & & 4 & 1 & 0 \\
\hline
\end{tabular}

Fonte: ESEB 2002, 2006 e 2010

Dessa forma, assim como aponta a literatura sobre o tema, essas medidas também apontam para um relativo número de assimilação das legendas no eleitorado. O dado positivo é a melhora do quadro atual quando comparado com o de 2006.

Entretanto, é possível ainda avaliar o grau de conexão entre partidos e eleitor por meio de medidas mais abrangentes, com o intuito de analisar o impacto dessa vinculação no comportamento dos eleitores, algo que já vem sendo trabalhado na literatura sobre o tema (PIMENTEL JR, 2007; CARREIRÃO E BARBETA, 2004; CARREIRÃO, 2008; MARTINS JR, 2010). O fato de os eleitores não conseguirem expressar de forma espontânea algum dos partidos do sistema político como seus representantes, ou como partidos que gostam, não necessariamente implica a inexistência de simpatias que podem ser utilizadas para a tomada de decisão do voto. Dessa forma, outra medida capaz de mensurar o nível partidário dos eleitores é uma medida de intensidade de quanto os eleitores gostam de cada um dos partidos. Nas rodadas do ESEB os eleitores foram indagados a responder o quanto gostam de determinados partidos políticos. No conteúdo da pergunta era dado o estímulo de qual partido deveria ser avaliado e uma escala de 0 a 10 para mensurar a intensidade do gosto dos eleitores por esse partido ${ }^{5}$.

O resultado dessa medida está na Tabela 4. Segundo essas informações, vemos que, em todos os anos estudados, o PT apresenta uma média de simpatia eleitoral maior que as dos demais partidos. Entretanto é necessário também

${ }_{5}$ Pergunta feita para mensurar o gusto dos eleitores dos eleitores pelos partidos foi a seguinte: "Por favor, use uma nota de 0 a 10 para indicar o quanto o(a) $\operatorname{Sr}(a)$ gosta do partido que eu vou mencionar." 
BRAGA, M. S. S. e PIMENTEL, J. Jr. Os partidos políticos brasileiros realmente não...

observar que a média de simpatia pelos demais partidos também encontra algum nível satisfatório. As notas de 7 a 10, que representam um alto grau de simpatia pelas legendas, mostram que quase metade dos eleitores declara gostar muito do PT em 2002, um número que diminui drasticamente em 2006 , passa para $32 \%$ e volta ao patamar semelhante na pesquisa de 2010, com $45 \%$, sendo essa uma tendência observada para todos os partidos pelos motivos já salientados anteriormente. Já o PSDB, partido que vem sendo o principal adversário na corrida presidencial nas últimas cinco eleições presidenciais, também aparece com percentual mais abrangente de simpatizantes comparado com as medidas de partidarismo com resposta espontânea, com 23\% dos entrevistados declarando gostar da legenda.

Por sua vez o PMDB, que aparece com número de simpatizantes semelhante ao PSDB, parece cair na avaliação dos eleitores. O PMDB já chegou a ser o partido mais popular do Brasil, quando alcançava níveis de preferência partidária espontânea acima de dois dígitos. Quando observamos a evolução da simpatia por essa legenda verificamos que, relativamente a 2002, apresenta em 2010 uma variação negativa. Outro partido que vem perdendo drasticamente a simpatia do eleitor é o PFL/DEM que, entre os partidos investigados, foi o que apresentou a maior redução de um pleito para outro.

Um destaque positivo pode ser dado ao número de simpatizantes do PV, com 25\%, que o coloca com um numero de simpatizantes parecido ao PMDB e PSDB. Com os dados existentes ${ }^{6}$ é impossível saber se PV teve algum crescimento; entretanto, dado o aumento na preferência espontânea dessa legenda, é bastante provável que sim.

\footnotetext{
6 Foi a primeira vez que o Eseb perguntou para os eleitores o quanto eles gostavam dessa legenda.
} 


\section{Tabela 4}

Simpatias partidárias

\begin{tabular}{|c|c|c|c|c|c|c|c|c|c|c|c|c|}
\hline & \multicolumn{4}{|c|}{2002} & \multicolumn{4}{|c|}{2006} & \multicolumn{4}{|c|}{2010} \\
\hline & $\begin{array}{l}0-3 \\
(\%)\end{array}$ & $\begin{array}{l}4-6 \\
(\%)\end{array}$ & $\begin{array}{c}7-10 \\
(\%)\end{array}$ & Média & $\begin{array}{l}0-3 \\
(\%)\end{array}$ & $\begin{array}{l}4-6 \\
(\%)\end{array}$ & $\begin{array}{l}7-10 \\
(\%)\end{array}$ & Média & $\begin{array}{l}0-3 \\
(\%)\end{array}$ & $\begin{array}{l}4-6 \\
(\%)\end{array}$ & $\begin{array}{l}7-10 \\
(\%)\end{array}$ & Média \\
\hline PT & 26 & 19 & 48 & 5,96 & 35 & 27 & 32 & 4,68 & 26 & 25 & 45 & 5,68 \\
\hline PSDB & 35 & 26 & 20 & 4,21 & 40 & 34 & 12 & 3,51 & 37 & 29 & 23 & 4,24 \\
\hline PMDB & 32 & 25 & 28 & 4,74 & 38 & 35 & 13 & 3,59 & 35 & 34 & 22 & 4,33 \\
\hline PDT & 39 & 22 & 13 & 3,62 & 42 & 34 & 6 & 3,09 & 40 & 28 & 8 & 3,28 \\
\hline $\begin{array}{l}\text { PFL/ } \\
\text { DEM }\end{array}$ & 39 & 23 & 18 & 3,85 & 46 & 32 & 7 & 2,95 & 43 & 21 & 6 & 2,78 \\
\hline PTB & 37 & 24 & 13 & 3,73 & 43 & 32 & 6 & 2,94 & 42 & 27 & 5 & 3,01 \\
\hline PV* & & & & & & & & & 30 & 31 & 25 & 4,61 \\
\hline PSOL* & & & & & & & & & 58 & 32 & 10 & 3,01 \\
\hline
\end{tabular}

Fonte: ESEB 2002, 2006 e 2010

*Não foram incluídos nas rodadas do ESEB de 2002 e 2006.

O efeito estruturante das eleições presidências sobre o comportamento políticoeleitoral no Brasil

\section{A simpatia partidária enquanto heurística afetiva}

A despeito da relativa incapacidade dos partidos serem expressos na preferência dos eleitores de maneira espontânea, pode-se observar uma grande quantidade de eleitores expressando preferências pelos partidos em termos de simpatia partidária ${ }^{7}$. A abrangência dessa medida nos oferece maior capacidade para avaliar o quanto os partidos impactam no comportamento dos eleitores e estruturam as escolhas eleitorais no Brasil.

\footnotetext{
7 Holzhacker \& Balbachevsky (2007:301) já demonstraram que entre as variáveis independentes que explicavam a decisão do voto no candidato petista em 2002 e 2006 a dimensão com maior poder preditivo era a simpatia e identidade com a candidatura Lula.
} 
BRAGA, M. S. S. e PIMENTEL, J. Jr. Os partidos políticos brasileiros realmente não...

Em termos teóricos, a partir dessa medida é possível mensurar os partidos brasileiros enquanto heurísticas afetivas dos eleitores para a tomada de decisão. Heurísticas são atalhos de julgamento que servem para organizar e simplificar informações complexas, auxiliando a criação de regras práticas utilizadas para a tomada de decisão. Nesse sentido, heurísticas equiparam-se ao conceito de atalhos de informação, tal como sugerido por Downs (1999); entretanto, distancia-se dele por conceber que não se trata de uma forma de diminuir o custo de informação para maximização de utilidade, mas sim, um processo psicológico não-consciente ativado com o objetivo de simplificar a tomada de decisão (LAU E REDLAWSK, 2006).

No caso aqui analisado, a simpatia ou afinidade dos eleitores pelos partidos, mensurada através desse termômetro afetivo ${ }^{8}$ que varia de 0 a 10 , seria um fator fundamental para se compreender como os eleitores decidem o voto, dado que a simpatia pelas legendas cria predisposições no comportamento eleitoral e oferece uma resposta mais eficiente e intuitiva para a decisão eleitoral. Nesse sentido, as predisposições afetivas dos eleitores pelas legendas atuariam no comportamento eleitoral da mesma forma como a identificação partidária, porém sem que necessariamente os eleitores assumam espontânea e claramente uma identidade junto a elas.

Essas predisposições afetivas em relação aos partidos seriam o resultado dos processos políticos que vão se internalizando subjetivamente no decorrer das eleições, conformando imagens mais favoráveis ou mais desfavoráveis em relação às legendas. Nesse sentido, tal como salientam Brady e Sniderman (1991:115) "o afeto por si mesmo pode ser o resíduo de uma longa biografia de transações cognitivas". Dentro dessa perspectiva, portanto, as simpatias partidárias seriam subprodutos do histórico de competições eleitorais, que formam impressões e estabelecem inclinações que enquadram a realidade político-eleitoral.

Baseado nesse princípio, o quanto de fato conta a simpatia dos eleitores pelas legendas para decidir o voto? A Tabela 5 mostra os resultados dos modelos de regressão logística multivariada para explicar o voto no segundo turno das eleições de 2002, 2006 e 2010.

Nessa tabela foi colocado no modelo 1 apenas a simpatia pelo PT e PSDB, uma vez que foram os candidatos dessas duas legendas que chegaram ao segundo turno nessas oportunidades (Lula contra Serra em 2002, Lula contra Alckmin em 2006 e Dilma contra Serra em 2010). Os índices de regressão logística (beta)

\footnotetext{
8 O conceito de "termômetro emocional" (feeling termometer) se refere ao termo utilizado por Levitin e Miller (1979) para mensurar os sentimentos dos eleitores em relação aos partidos dentro do espectro ideológico.
} 
mostram uma correlação positiva entre a simpatia pelo PT e o voto no candidato no PT (ou, o contrário, uma correlação entre simpatia pelo PSDB e voto no candidato do $\left.\operatorname{PSDB}^{9}\right)$.

O $\mathrm{R}^{2}$ de Nagelkerke apresenta valores relativamente altos já no modelo 1 e a inclusão de apenas esses dois partidos no modelo nos explica a maioria da variância observada. A inclusão dos demais partidos no modelo 2, apesar de estatisticamente significantes nos casos de 2002 e 2006 para alguns deles, agregam pouco para explicar a variância final da variável dependente. No caso de 2010, mesmo a inclusão de um terceiro modelo, com PV e PSOL, não agrega em praticamente nada para a variância explicada, além do que, para esse ano, os índices de regressão entre simpatia pelos demais partidos, tanto no modelo 2 quanto no modelo 3 , se mostraram estatisticamente não significantes.

Além disso, no decorrer dessas três pesquisas é possível notar um sucessivo aumento no $\mathrm{R}^{2}$ de Nagelkerke, revelando que a capacidade explicativa dessas variáveis partidárias aumenta no decorrer desses anos. Nota-se possível ainda um aumento nos índices de regressão que correlacionam a simpatia pelo PT e PSDB e o voto nessas legendas. Em especial, é bastante considerável o aumento nos índices de regressão para a simpatia pelo PSDB, que passou de -0,816 em 2002, -1,093 em 2006, para -1,341 em 2010, indicando uma acréscimo na capacidade dessa variável explicar o voto. Em suma, esses modelos apontam para uma crescente capacidade da simpatia pelo PT e PSDB polarizar o eleitorado, tornando essa variável considerável para compreender o comportamento dos eleitores e explicar o resultado final dos pleitos.

\footnotetext{
${ }^{9}$ Como a variável dependente é uma variável dummy, a correlação negativa da simpatia pelo PSDB com voto no candidato do PT também significa seu inverso, ou seja, uma correlação positiva com o voto no candidato do PSDB, com o mesmo valor do indice de regressão beta.
} 
BRAGA, M. S. S. e PIMENTEL, J. Jr. Os partidos políticos brasileiros realmente não...

Tabela 5

Regressão binária logística- simpatias partidárias e voto.

\begin{tabular}{|c|c|c|c|c|c|c|c|}
\hline & \multicolumn{2}{|c|}{2002} & \multicolumn{2}{|c|}{2006} & \multicolumn{3}{|c|}{2010} \\
\hline & \multicolumn{2}{|c|}{ Modelos } & \multicolumn{2}{|c|}{ Modelos } & \multicolumn{3}{|c|}{ Modelos } \\
\hline & 1 & 2 & 1 & 2 & 1 & 2 & 3 \\
\hline \multirow[t]{2}{*}{ PT } & $1,456 * * *$ & $1,465^{* * *}$ & $1,987 * * *$ & $1,884 * * *$ & $1,835^{* * *}$ & $1,872 * * *$ & $1,887^{* * *}$ \\
\hline & $(4,287)$ & $(4,328)$ & $(7,291)$ & $(6,579)$ & $(6,266)$ & $(6,5)$ & $(6,598)$ \\
\hline \multirow[t]{2}{*}{ PSDB } & $-0,816 * * *$ & $-0,632 * * *$ & $-1,093^{* * *}$ & $-1,197 * * *$ & $-1,341^{* * *}$ & $-1,306^{* * *}$ & $-1,277^{* * *}$ \\
\hline & $(0,442)$ & $(0,532)$ & $(0,335)$ & $(0,302)$ & $(0,261)$ & $(0,271)$ & $(0,279)$ \\
\hline \multirow[t]{2}{*}{ PMDB } & & $-0,330 * * *$ & & $-0,704^{* *}$ & & $.0,237$ & $.0,239$ \\
\hline & & $(0,719)$ & & $(0,495)$ & & $(0,789)$ & $(0,787)$ \\
\hline \multirow[t]{2}{*}{ PFL/DEM } & & $-0,303^{* *}$ & & 0,303 & & $.0,142$ & $.0,211$ \\
\hline & & $(0,739)$ & & $(1,353)$ & & $(0,888)$ & $(0,810)$ \\
\hline \multirow[t]{2}{*}{ PTB } & & $0,291 * *$ & & 0,129 & & 0,066 & 0,047 \\
\hline & & $(1,338)$ & & $(1,138)$ & & $(1,069)$ & $(1,048)$ \\
\hline \multirow[t]{2}{*}{ PDT } & & $.0,118$ & & 0,582 & & 0,190 & 0,174 \\
\hline & & $(0,889)$ & & $(1,790)$ & & $(1,210)$ & $(1,190)$ \\
\hline \multirow[t]{2}{*}{ PV } & & & & & & & $.0,157$ \\
\hline & & & & & & & $(0,855)$ \\
\hline \multirow[t]{2}{*}{ PSOL } & & & & & & & 0,249 \\
\hline & & & & & & & $(1,283)$ \\
\hline Constante & $-0,733^{* *}$ & $.0,194$ & $-0,666^{*}$ & $.0,671$ & $-0,816^{* *}$ & $\cdot 0,716^{*}$ & $-0,727^{*}$ \\
\hline $\begin{array}{l}\mathbf{R}^{2} \\
\text { Nagelkerke }\end{array}$ & 0,403 & 0,424 & 0,440 & 0,462 & 0,522 & 0,525 & 0,528 \\
\hline $\mathbf{N}$ & 1571 & 1299 & 688 & 632 & 1555 & 1059 & 1030 \\
\hline
\end{tabular}

Fonte: ESEB 2002, 2006 e 2010

Nota: Razão de Chance (Odds Ratio) em parênteses.

Variáveis independentes: grau de simpatia pelos partidos de 0 a $3=1$, de 4 a $6=2$, de 7 a $10=3$.

Variável dependente: voto no candidato do PT $=1$; voto no candidato do PSDB $=0$; Outros casos= missing cases.

${ }^{* * *} p<.001 ;{ }^{* *} p<.01 ; * p<.05$ 


\section{Sofisticação e heurística partidária}

A literatura sobre o partidarismo no Brasil vem apontando para uma forte correlação entre níveis cognitivos e a capacidade de os eleitores utilizarem os partidos para a tomada de decisão eleitoral (BALBACHEVSKY, 1992; CASTRO, 1994; KINZO E CARREIRÃO, 2004; KINZO, 2005). O partidarismo nessa perspectiva seria um recurso bastante sofisticado, mais utilizado pelos eleitores de maior escolaridade e aqueles com grande envolvimento político. No entanto, essas conclusões têm sido aferidas com base na medida espontânea de preferência partidária que, de fato, oferece obstáculos aos eleitores menos sofisticados para expressarem um partido preferido, dado o baixo recall espontâneo que as legendas possuem. Entretanto, o fato de os eleitores não conseguirem expressar espontaneamente um partido, não significa necessariamente que eles não têm simpatias por alguns deles. Assim, a partir da medida de simpatia partidária é possível medir o impacto dos partidos no voto em nível intuitivo entre aqueles que, pelo baixo envolvimento e sofisticação, não conseguem expressá-los espontaneamente.

É possível dizer que a simpatia partidária é uma heurística igualmente utilizada por eleitores mais e menos sofisticados? A primeira coisa a avaliar em relação a essa questão é a capacidade de os eleitores se posicionarem na escala afetiva, verificando o número de não respostas e não conhecimento dos partidos, por nível de escolaridade. Na Tabela 6 , podemos verificar que de fato os eleitores com maior escolaridade tendem a se posicionar mais em relação aos partidos na escala afetiva, do que os eleitores menos escolarizados, principalmente no que concerne ao maior conhecimento que os eleitores possuem dos partidos. Eleitores com menor escolaridade tendem a expressar mais que não conhecem as legendas (NC= não conhecem) do que os eleitores com maior escolaridade. Entretanto, quanto ao PT, PSDB e PMDB, houve uma queda no nível do desconhecimento dos eleitores e um acréscimo no percentual de respostas no decorrer dos anos avaliados, sobretudo dentre os eleitores com menor escolaridade, mostrando que essas legendas têm se tornado mais conhecidas e mais eleitores têm conseguido expressar graus de simpatia por elas. Nesse sentido, ao menos no que concerne esses três partidos, o bom numero de respostas na escala afetiva, demonstra a abrangência da escala para mensurar simpatia, mesmo para os eleitores com menor escolaridade.

Essa tabela reforça a idéia de que esses partidos têm ampliado seu conhecimento pelo eleitorado. O PMDB, apesar de não ter lançado candidatura para presidente nas eleições analisadas aparece com maior visibilidade no eleitorado 
também. No caso, a hipótese explicativa é a reminiscência de alguma simpatia por essa legenda no passado, o papel central que vem desempenhando nas coalizões de governo e a sua grande inserção no poder local, tendo o maior numero de prefeitos eleitos nas ultimas eleições municipais. Também ocorre um crescimento no desconhecimento das legendas PDT, PTB e PFL/DEM de 2006 para 2010. No caso deste último partido, esse aumento se deve obviamente à mudança de nome da legenda, ocorrido em 2007. 
OPINIÃO PÚBLICA, Campinas, vol. 17, n², Novembro, 2011, p.271-303

Tabela 6

Nível de não resposta e não conhecimento, segundo escolaridade

\begin{tabular}{|c|c|c|c|c|c|c|c|c|c|}
\hline & \multicolumn{9}{|c|}{2002} \\
\hline & \multicolumn{3}{|c|}{ Ginásio } & \multicolumn{3}{|c|}{ Colégio } & \multicolumn{3}{|c|}{ Superior } \\
\hline & $\begin{array}{l}\mathrm{NC}^{*} \\
(\%)\end{array}$ & NS/NR & $\begin{array}{l}\text { Missing } \\
\text { Cases }\end{array}$ & $\begin{array}{l}\mathrm{NC}^{*} \\
(\%)\end{array}$ & NS/NR & $\begin{array}{l}\text { Missing } \\
\text { Cases }\end{array}$ & $\begin{array}{l}\mathrm{NC}^{*} \\
(\%)\end{array}$ & NS/NR & $\begin{array}{c}\text { Missing } \\
\text { Cases }\end{array}$ \\
\hline PT & 5 & 6 & 11 & 1 & 3 & 4 & ${ }^{\circ}$ & 0 & 0 \\
\hline PMDB & 12 & 7 & 19 & 6 & 3 & 9 & 5 & 4 & 9 \\
\hline PDT & 23 & 8 & 31 & 15 & 6 & 21 & 8 & 7 & 14 \\
\hline PTB & 22 & 9 & 31 & 15 & 7 & 21 & 12 & 6 & 17 \\
\hline PSDB & 16 & 8 & 24 & 8 & 5 & 13 & 5 & 4 & 9 \\
\hline \multirow[t]{2}{*}{ PFL } & 16 & 8 & 25 & 9 & 5 & 14 & 6 & 5 & 12 \\
\hline & \multicolumn{9}{|c|}{2006} \\
\hline PT & 2 & 6 & 8 & 2 & 3 & 5 & 1 & 1 & 1 \\
\hline PMDB & 7 & 9 & 16 & 5 & 5 & 9 & 7 & 1 & 8 \\
\hline PDT & 12 & 8 & 20 & 10 & 6 & 16 & 9 & 1 & 9 \\
\hline PTB & 12 & 9 & 21 & 8 & 6 & 14 & 9 & 1 & 10 \\
\hline PSDB & 9 & 8 & 17 & 6 & 4 & 9 & 6 & 1 & 6 \\
\hline \multirow[t]{2}{*}{ PFL } & 11 & 9 & 19 & 7 & 4 & 11 & 8 & 1 & 8 \\
\hline & \multicolumn{9}{|c|}{2010} \\
\hline PT & 2 & 5 & 6 & 0 & 1 & 2 &. & 2 & 2 \\
\hline PMDB & 4 & 7 & 11 & 4 & 4 & 8 & 2 & 4 & 5 \\
\hline PDT & 17 & 9 & 26 & 16 & 7 & 23 & 10 & 4 & 14 \\
\hline PTB & 20 & 10 & 30 & 17 & 7 & 24 & 9 & 6 & 15 \\
\hline PSDB & 7 & 7 & 13 & 3 & 4 & 7 & 1 & 3 & 4 \\
\hline PV & 12 & 8 & 20 & 9 & 4 & 13 & 1 & 4 & 5 \\
\hline DEM & 26 & 10 & 36 & 20 & 7 & 26 & 10 & 5 & 15 \\
\hline PSOL & 24 & 10 & 34 & 16 & 6 & 22 & 5 & 5 & 10 \\
\hline
\end{tabular}

Fonte: ESEB 2002, 2006 e 2010

*Não conhece o partido.

Tendo em vista a boa abrangência de respostas desses partidos no eleitorado, a questão centra-se na análise das simpatias partidárias enquanto heurística para a tomada de decisão do voto apenas para os dois principais partidos na disputa presidencial, PT e PSDB. A Tabela 7 mostra o resultado de regressão logística entre simpatias partidárias e a intenção de voto no segundo turno das ultimas três eleições, para cada nível de escolaridade. Podemos verificar que em 
BRAGA, M. S. S. e PIMENTEL, J. Jr. Os partidos políticos brasileiros realmente não...

qualquer grau de escolaridade analisado existe correlação entre voto e simpatia partidária nos três pleitos examinados, sob uma tendência geral de quanto maior a escolaridade, maior os índices de regressão logística. Outra constatação é a de que há um aumento no decorrer dos anos nos índices de regressão logística nos níveis de escolaridade mais BA ixa para o PSDB, indicando que a simpatia por esse partido tem se tornado cada vez mais relevante também entre os eleitores com menor sofisticação política.

Tabela 7

\section{Regressão logística binária- simpatia pelo PT e PSDB e voto por faixa de escolaridade.}

\begin{tabular}{|c|c|c|c|c|c|c|c|c|c|}
\hline & \multicolumn{3}{|c|}{2002} & \multicolumn{3}{|c|}{2006} & \multicolumn{3}{|c|}{2010} \\
\hline & Gin. & Col. & Sup. & Gin. & Col. & Sup. & Gin. & Col. & Sup. \\
\hline \multirow{2}{*}{ PT } & $1,230 * * *$ & $1,677^{* * *}$ & $1,773 * * *$ & $2,063^{* * *}$ & $2,173 * * *$ & $1,517^{* * *}$ & $1,511 * * *$ & $1,811 * * *$ & $2,405^{* * *}$ \\
\hline & $(3,420)$ & $(5,35)$ & $(5,891)$ & $(7,867)$ & $(8,781$ & $(4,559)$ & $(4,532)$ & $(6,563)$ & $(11,080)$ \\
\hline \multirow{2}{*}{ PSDB } & $-0,705^{* * *}$ & $-0,816 * * *$ & $-1,520 * * *$ & $-1,031^{* * *}$ & $-1,399 * * *$ & $-1,769 * * *$ & $-1,311^{* * *}$ & $-1,309 * * *$ & $1,651^{* * *}$ \\
\hline & $(0,490)$ & $(0,442)$ & $(0,219)$ & $(0,357)$ & $(0,247)$ & $(0,170)$ & $(0,270)$ & $(0,270)$ & $(0,192)$ \\
\hline Constante & $.0,470$ & 1,335 & 0,421 & $.0,68$ & $.0,607$ & 0,457 & $.0,297$ & $-1,114$ & $-1,799$ \\
\hline$R^{2}$ Nagelkerke & 0,319 & 0,467 & 0,582 & 0,441 & 0,472 & 0,469 & 0,468 & 0,509 & 0,642 \\
\hline $\mathbf{N}$ & 898 & 539 & 134 & 413 & 179 & 78 & 861 & 484 & 210 \\
\hline
\end{tabular}

Fonte: ESEB 2002, 2006 e 2010

Nota: Razão de Chance (Odds Ratio) em parênteses.

Variaveis independentes: grau de simpatia pelos partidos de 0 a $3=1$, de 4 a $6=2$, de 7 a $10=3$.

Variável dependente: voto no candidato do PT $=1$; voto no candidato do PSDB $=0$; Outros casos $=$ missing cases.

$* * * p<.001 ; * * p<.01 ; * p<.05$ 


\section{Simpatia partidária e comportamento eleitoral}

Os dados apresentados nos modelos de regressão logística denotam que os partidos não são tão irrelevantes quanto grande parte da literatura sobre o tema defende. Ao contrário, revela que a simpatia pelo PT e PSDB vem crescendo para a definição do voto no Brasil. Ao que tudo indica, os eleitores tornaram-se mais familiarizados com os partidos devido ao embate entre as candidaturas presidenciais dessas legendas, criando simpatias e antipatias. Apesar de o PSDB não contar com uma grande quantidade de eleitores que expressam espontaneamente preferência por essa legenda, a simpatia por esse partido parece estar desempenhando papel cada vez mais importante para a decisão do voto, mesmo entre os eleitores com menor escolaridade.

Não obstante, a simpatia dos eleitores pelas legendas para a definição do voto precisa ser relativizada. Afinal, em comparação com outras variáveis, qual seria a contribuição dessa simpatia para o comportamento eleitoral? Para introduzir uma resposta a essa questão, na Tabela 8 apresentamos o índice de correlação gama para as principais variáveis explicativas do voto presentes na literatura e a declaração do voto no segundo turno nas três ultimas eleições.

$\mathrm{Na}$ literatura recente sobre as eleições presidenciais muita ênfase tem sido dada às variáveis socioeconômicas como fator de explicação do voto (SINGER, 2009, 2010; HOLZHACKER E BALBACHEVSKY, 2007; VEIGA, 2007; BOHN, 2011; MARTINS JR., 2009), sobretudo as variáveis renda e escolaridade. Tal literatura aponta que as políticas sociais e a ênfase do governo Lula no combate à fome e à pobreza teriam contribuído para alinhar os eleitores mais pobres ao PT, enquanto a classe média tenderia a votar mais no PSDB.

Como mostra a Tabela 8, desde 2002 a renda esteve correlacionada com o voto nos candidatos de maneira estatisticamente significativa, sendo que quanto maior a renda, menor a tendência de voto no candidato do PT, ou seja, mesmo antes do governo Lula e de suas políticas sociais, podemos perceber uma ligeira tendência de voto de segmentos populares no PT. Entretanto, vale ressaltar que em 2002 essa correlação era quase nula, enquanto 2006 apresenta uma correlação mais forte, e indica a força do governo Lula em aprofundar a tendência já existente em 2002.

Em 2010, a renda parece ter perdido importância relativamente a 2006, tendo o índice de correlação diminuído consideravelmente, e pondo em xeque essa variável como um componente relevante para a decisão eleitoral. Por sua vez, a variável escolaridade, considerada uma proxy de renda, também esteve correlacionada ao voto no PT em 2006 e em 2010; entretanto, a exemplo do que se 
observa com a variável renda, perdeu vigor para explicar o voto na candidata dessa legenda em 2010.

Juntamente com as variáveis renda e escolaridade, as regiões do país têm sido enfatizadas como preditoras do comportamento eleitoral. Na Tabela 8 é possível observar que de fato existe correlação entre determinadas regiões e voto para presidente. Em 2002, apenas o Nordeste aparecia tendendo a votar no PT, algo que se manteve nas outras duas eleições subseqüentes. Em 2006, Norte/Centro Oeste tenderam ao voto petista e Sul e Sudeste ao voto pesedebistas, enquanto em 2010, observamos que o Centro-Oeste e o Sul tenderam a se posicionar contrários ao PT.

Outra característica social enfatizada na literatura é o sexo dos eleitores. Nesse caso observa-ser uma tendência do eleitorado feminino não votar no PT em 2002, de maneira bastante fraca; e em 2006, como uma correlação moderada, não se observando correlação significativa em 2010. A tendência das mulheres não votarem no PT já foi observado em outros trabalhos e os dados aqui presentes corroboram isso (FERNANDES, 2006; MARTINS JR., 2009).

A idade dos eleitores, variável ainda não muito explorada pela literatura, apresentou algumas variações. Enquanto em 2002 e 2006 os mais jovens tenderam a votar no PT (ou o contrário, os mais velhos a votarem no PSDB) em 2010 essa variável não apresentou significância para explicar o voto nos candidatos.

A avaliação de governo, outra variável considerada fundamental para explicar o voto no Brasil (CARREIRÃO, 2002, ALMEIDA, 2008, HOLZHACKER \& BALBACHEVSKY, 2007, MENEGUELLO, 2007) também apresentou grande correlação com o voto em todas as eleições, principalmente para explicar a vitória de Lula em 2006. Em 2010, apesar de ter sido fundamental para a vitória de Dilma, dado o alto nível de popularidade do governo Lula, o nível de correlação foi menor.

Também consideramos nessa análise a identidade ideológica dos eleitores, tal como salientada por Singer (1999). Nesse caso, há correlação entre ideologia e voto nos anos de 2002 e 2010, sendo que quanto mais à direita, menor a tendência de voto no PT. Os índices de correlação dessa variável com o voto precisam ser relativizados, uma vez que o número de não respostas para o posicionamento ideológico foi bastante alto nessas pesquisas ${ }^{10}$. Isso nos permite prever o voto para um contingente menor de eleitores, sobretudo entre aqueles com maior capacidade

\footnotetext{
10 Em 2002 o numero de não resposta para essa questão foi de 23\%, em 2006, 42\%, e em 2010 , $45 \%$. Uma hipótese para o aumento de não respostas a partir de 2006 é o fato de que a chegada do PT ao governo tenha embaralhada o continuo esquerda - direita e os eleitores tenham perdido as referencias partidárias para se posicionarem no espectro ideológico.
} 
de entender a escala e os conceitos de esquerda e direita, tal como bem salienta Carreirão (2007).

Por fim, no que concerne à variável simpatia partidária, de maneira geral, as variáveis simpatia pelo PT e PSDB estiveram fortemente correlacionadas ao voto no candidato do PT no segundo turno das três eleições estudadas. Fica evidente que os eleitores simpáticos ao PT tenderam a votar no candidato petista, enquanto os eleitores simpáticos ao PSDB votaram no candidato tucano.

Tabela 8

Correlação gama - variáveis demográficas e atitudinais e voto

\begin{tabular}{|c|c|c|c|}
\hline & 2002 & 2006 & 2010 \\
\hline Sexo & $0,094 *$ & $0,205^{* *}$ & 0,063 \\
\hline Idade & $-0,093^{*}$ & $-0,115^{*}$ & $.0,003$ \\
\hline Escolaridade & $.0,007$ & $-0,411 * * *$ & $-0,122 * *$ \\
\hline Renda & $-0,079 *$ & $-0,360 * * *$ & $-0,117^{* *}$ \\
\hline Norte & $.0,164$ & - & $.0,117$ \\
\hline Centro Oeste & $.0,183$ & - & $-0,207 * *$ \\
\hline Norte/Centro Oeste & - & $0,323 * *$ & . \\
\hline Nordeste & $0,216 * * *$ & $0,509 * * *$ & $0,305 * * *$ \\
\hline Sudeste & $.0,036$ & $-0,220 * *$ & $.0,006$ \\
\hline Sul & $.0,104$ & $-0,513 * * *$ & $-0,273 * * *$ \\
\hline Avaliação de Governo & $-0,483 * * *$ & $0,904 * * *$ & $0,687 * * *$ \\
\hline Simpatia pelo PT & $0,762 * * *$ & $0,805^{* * *}$ & $0,770 * * *$ \\
\hline Simpatia pelo PSDB & $-0,457 * * *$ & $-0,399 * * *$ & $-0,600 * * *$ \\
\hline Ideologia & $-0,398 * * *$ & $-0,131$ & $-0,256^{* * *}$ \\
\hline
\end{tabular}

Fonte: ESEB 2002, 2006 e 2010

Variáveis independentes: Sexo: $F=1, M=2$; Idade: de 16 a $24=1,25$ a $45=2$, 45 ou mais=3; Escolaridade: Até Ginásio completo= 1; Colégio= 2; Superior=3; Renda: 1 a $2 \mathrm{SM}=1 ; 2$ a $5 \mathrm{SM}$ $=2 ; 5$ a $10 \mathrm{SM}=3$, Mais de $10 \mathrm{SM}=4$, NS/NR= missing cases; Região Norte= 1, outras =0; Região Nordeste $=1$, outras $=0$; Região Norte/Centro $=1$, outras $=0$, Região Sudeste $=1$, outras $=0$, Região Sul=1, outras=0; Avaliação de Governo em 2002: Ruim/Péssimo= 1; Regular=2; Muito bom/bom=3, NS/NR= missing cases; Avaliação de Governo 2006/2010: Péssimo=1, Ruim=2, Bom=3, Muito bom, NS/NR= missing cases $=4$; grau de simpatia pelos PT e PSDB de 0 a $3=1$, de 4 a $6=2$, de 7 a $10=3$, NS/NR= missing cases; Ideologia: 0 a 3 (esquerda) $=1$, de 4 a 6 (centro) $=2$, de 7 a 10 (direita) $=3, \mathrm{NS} / \mathrm{NR}=$ missing cases.

Variável dependente: voto no candidato do PT $=1$; voto no candidato do PSDB $=0$; Outros casos $=$ missing cases. ${ }^{* *} p<.001 ;{ }^{* *} p<.01 ;{ }^{*} p<.05$ 
Para analisarmos o peso relativo do partidarismo vis a vis outras variáveis, a Tabela 9 mostra os cinco modelos multivariados de regressão logística, utilizando essas mesmas variáveis, para cada um dos anos estudados, 2002, 2006 e 2010. No modelo 1 encontram-se as variáveis socioeconômicas; no modelo 2 foram incluídas também as regiões do pais, no modelo 3 foi introduzida a avaliação de governo; no modelo 4 encontram-se também as simpatias por PT e PSDB e, por fim, no modelo 5 foi incluída a variável ideologia. A inclusão das sucessivas variáveis serve para analisar a variância explicada de cada um dos modelos para a variável dependente.

As interpretações possíveis desses modelos não diferem das apresentadas pelos índices de correlação, presentes na Tabela 5. Tratando-se das variáveis socioeconômicas, em todos os anos a capacidade explicativa do modelo 1 é bastante pequena, tal como sugere o $\mathrm{R}^{2}$ Nagelkerke. A baixa capacidade de explicação dessas variáveis é um aspecto já salientado anteriormente por Martins Jr (2007), ou seja, saber o perfil do eleitor não ajuda a entender muito como ele irá se comportar nos pleitos e prever seu voto.

$\mathrm{O}$ ano em que as variáveis socioeconômicas se desempenham melhor para explicar o voto é o de 2006, quando o modelo 1 atinge um $\mathrm{R}^{2}$ de 0,099, mesmo assim um valor bastante baixo.

Em especial, no que concerne à variável renda, desde 2002, observa-se uma tendência de voto dos mais pobres no candidato do PT. Esse dado reforça os achados de Bohn (2011) e Singer (2010), que apontavam já em 2002 uma tendência petista no eleitorado mais popular, implicando que a mudança de base eleitoral do PT não seria decorrente da implementação de políticas sociais do governo Lula, sobretudo o Bolsa Família, mas seria anterior ao seu governo.

Não obstante, a inclusão de outras variáveis nos modelos de regressão seguinte trata de mitigar a capacidade explicativa da variável renda, tornando-a estatisticamente não significante. A exceção é o ano de 2006, em que a renda apresenta valores significantes em todos os modelos analisados. Em 2010, essa variável claramente perde o vigor para explicar o voto, deixando de ser estatisticamente significante a partir do modelo 2, e sinalizando que o alinhamento entre eleitorado mais pobre e o PT é bastante frágil.

É possível observar também nesses dados que a região Nordeste já aparecia em 2002 alinhada ao voto no PT, tal como mostram os modelos 2 e 3 da Tabela 9. Esse dado reforça a hipótese de Bohn (2011) de que não foram os programas sociais de distribuição de renda que fizeram os eleitores se alinharem com o PT, uma vez que a região Nordeste, região mais beneficiada pelo Bolsa Família, já apresentava essa tendência mesmo antes do governo Lula. 
Em todos os anos analisados, a inclusão de variáveis atitudinais, a partir do modelo 3, agregaram de maneira substantiva a capacidade de explicação do voto, como indica o $\mathrm{R}^{2}$ Nagelkerke. A avaliação de governo desempenhou papel mais importante para explicar o voto na eleição de 2006, quando Lula se reelegeu, conforme o alto valor assumido pelo índice de regressão linear. Em 2010, a capacidade da avaliação de governo em explicar o voto foi menor. A razão disso é simples: é muito mais razoável transformar popularidade em voto quando o candidato é o próprio incumbente do que transferir a popularidade do incumbente para o voto em um candidato apoiado por ele.

As variáveis de simpatia partidária por PT e PSDB, incluídas a partir do modelo 4, apresentaram grande capacidade explicativa nas eleições analisadas e contribuem de forma substantiva para elevar a variância explicada em todas elas. Os índices de regressão obtidos nos modelos foram bastante elevados, mesmo quando controlados pelas outras variáveis. Alem disso, em comparação com outras variáveis utilizadas para entender o comportamento eleitoral, a simpatia é mais fundamental para se entender a razão do voto em duas oportunidades, em 2002 e em 2010, quando os índices de regressão logísticas encontrados são maiores do que os apresentados por qualquer outra variável analisada. 
BRAGA, M. S. S. e PIMENTEL, J. Jr. Os partidos políticos brasileiros realmente não...

Tabela 9

Regressão logística binária - variáveis demográficas e atitudinais e o voto para presidente $-2^{\circ}$ turno

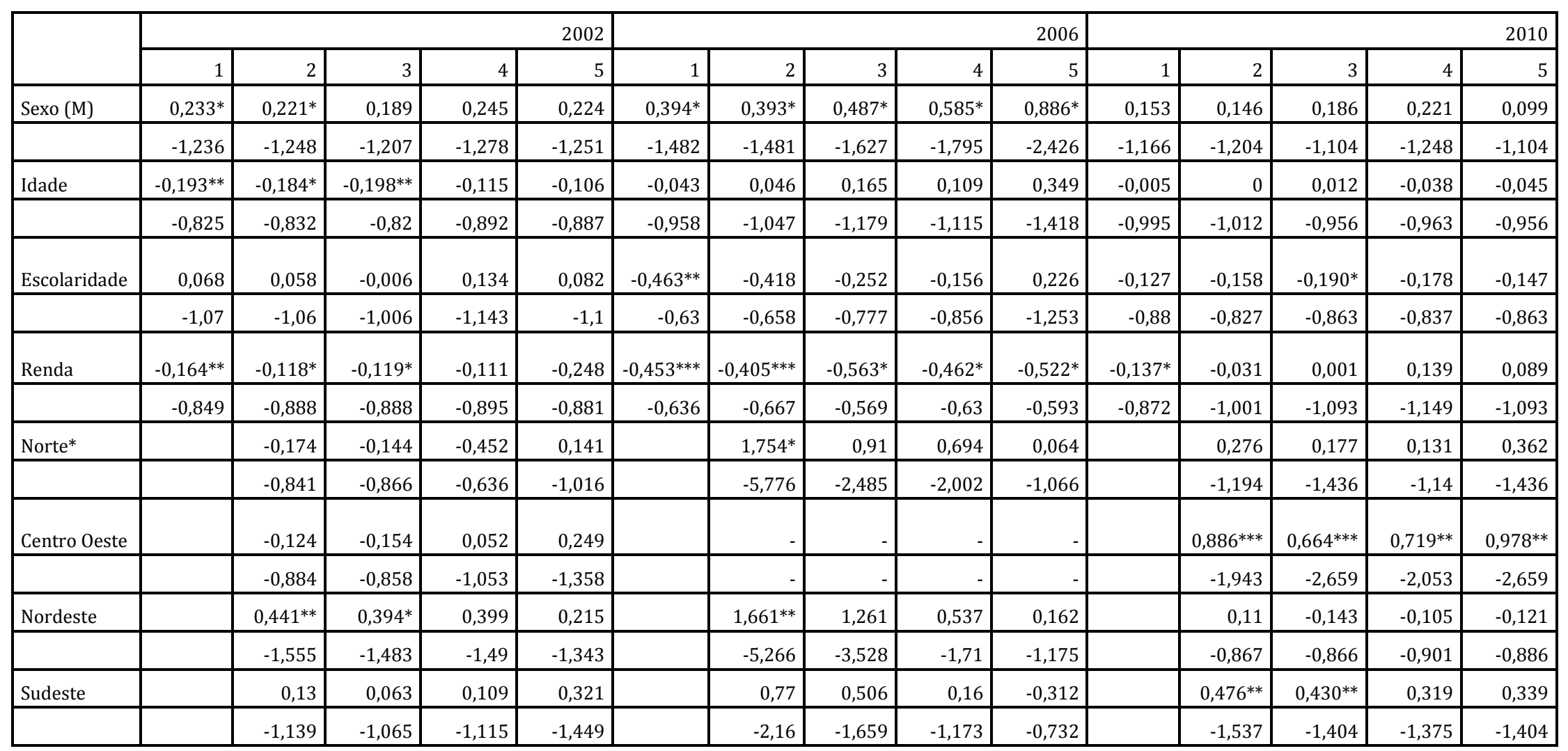


OPINIÃO PÚBLICA, Campinas, vol. 17, n², Novembro, 2011, p.271-303

\begin{tabular}{|c|c|c|c|c|c|c|c|c|c|c|c|c|c|c|c|}
\hline $\begin{array}{l}\text { Aval. de } \\
\text { Governo }\end{array}$ & & & $-0,676^{* * *}$ & $-0,521^{* * *}$ & $-0,566^{* * *}$ & & & $3,215^{* * *}$ & $2,769^{* * *}$ & $3,323^{* * *}$ & & & $1,498^{* * *}$ & $0,924 * * *$ & $0,914^{* * *}$ \\
\hline & & & $-0,509$ & $-0,594$ & $-0,568$ & & & $-24,903$ & $-15,95$ & $-27,746$ & & & $-2,495$ & $-2,519$ & $-2,495$ \\
\hline Simpatia PT & & & & $1,406^{* * *}$ & $1,369^{* * *}$ & & & & $1,520^{* * *}$ & $1,918^{* * *}$ & & & & $1,541^{* * *}$ & $1,676^{* * *}$ \\
\hline & & & & $-4,08$ & $-3,931$ & & & & $-4,573$ & $-6,807$ & & & & $-4,671$ & $-5,347$ \\
\hline $\begin{array}{l}\text { Simpatia } \\
\text { PSDB }\end{array}$ & & & & $-0,741^{* * *}$ & $-0,776^{* * *}$ & & & & $-1,399 * * *$ & $-1,358^{* * *}$ & & & & $-1,329 * * *$ & $-1,273^{* * *}$ \\
\hline & & & & $-0,477$ & $-0,46$ & & & & $-0,247$ & $-0,257$ & & & & $-0,265$ & $-0,28$ \\
\hline Ideologia & & & & & $-0,398^{* * *}$ & & & & & $-0,804^{*}$ & & & & & $-0,441^{* *}$ \\
\hline & & & & & $-0,672$ & & & & & $-0,447$ & & & & & $-0,643$ \\
\hline Constante & $1,379^{* * *}$ & $1,120^{* * *}$ & $2,653^{* * *}$ & 0,354 & 0,062 & $3,304^{* * *}$ & $1,183^{* * *}$ & $-4,234^{* *}$ & $-3,571^{* * *}$ & $-4,399$ & $0,832^{* * *}$ & 0,215 & $-4,530^{* * *}$ & $-3,622^{* * *}$ & $-2,946^{* *}$ \\
\hline $\begin{array}{l}\text { R2 } \\
\text { Nagelkerke }\end{array}$ & 0,015 & 0,024 & 0,125 & 0,445 & 0,482 & 0,099 & 0,18 & 0,493 & 0,631 & 0,705 & 0,011 & 0,038 & 0,213 & 0,542 & 0,601 \\
\hline $\mathrm{N}$ & 1931 & 1931 & 1904 & 1556 & 1321 & 716 & 716 & 709 & 633 & 419 & 1699 & 1699 & 1688 & 1510 & 906 \\
\hline
\end{tabular}

Fonte: ESEB 2002, 2006 e 2010

Nota: Razão de Chance (Odds Ratio) em parênteses.

Variáveis independentes:

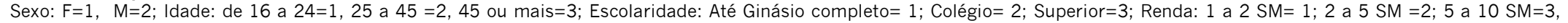

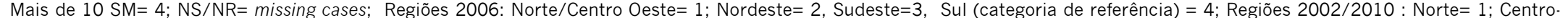

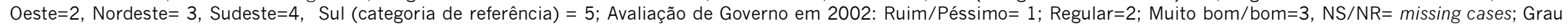

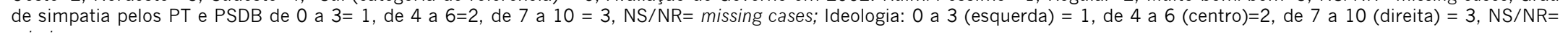
missing cases.

Variável dependente:

Voto no candidato do PT = 1 ; voto no candidato do PSDB = 0; Outros casos= missing cases.

*** $p<.001 ; * * p<.01 ; * p<.05$ 
BRAGA, M. S. S. e PIMENTEL, J. Jr. Os partidos políticos brasileiros realmente não...

Vale também ressaltar a questão da identidade ideológica na tabela anterior. Em todos os anos analisados há relação entre identidade ideológica e voto, sendo que, quanto mais à esquerda, maior a tendência de voto no PT e menor no PSDB. Entretanto, dado que o número de entrevistados que respondem essa questão está em torno de metade das amostras, não podemos generalizar esse achado para todo o eleitorado, limitando a identidade ideológica a uma explicação do voto apenas para uma parte do eleitorado. Mesmo nesse caso, as simpatias partidárias continuam tendo peso mais significativo para explicar o comportamento dos eleitores.

Esses dados são persuasivos em apontar a importância das simpatias partidárias para explicar o voto no Brasil. Apesar de o número de eleitores que expressam preferência espontânea por uma das legendas ser razoavelmente baixo, os partidos têm conseguido se estabelecer na subjetividade dos eleitores, formando preferências e visões políticas diferenciadas, de tal forma que eleitores que gostam do PT tendem a votar nessa organização partidária, enquanto eleitores que gostam do PSDB tendem a votar em candidatos desse partido.

Ao que tudo indica, essas tendências têm sido criadas pelos efeitos mecânicos e psicológicos do sistema eleitoral majoritário que rege as eleições presidenciais e pelas lutas político-programáticas entre esses partidos, no papel de governo e oposição. Esses efeitos têm afetado inclusive o comportamento eleitoral dos menos escolarizados, mesmo que isso incida de forma mais tênue. Assim sendo, se os principais partidos brasileiros, depois de participarem de seis pleitos presidenciais não alcançaram relevância do ponto de visto cognitivo, ao menos encontram relevância do ponto de vista emocional-intuitivo, constituindo importante heurística para o comportamento dos eleitores. Essa dinâmica político-eleitoral vem sustentando a luta política entre essas organizações e tornando a disputa presidencial centrada nelas, estruturando dessa forma, um sistema bipartidário ao nível da disputa nacional.

\section{Considerações finais}

Em síntese, esta análise mostrou que partidos políticos importam para explicar o comportamento dos eleitores brasileiros e, portanto, para a estruturação do sistema partidário contemporâneo. Como vimos, os indicadores de representação e de preferência partidária (entendida como gosto por algum partido) revelaram que, para quase metade dos eleitores os partidos fazem algum sentido, seja do ponto de vista da representação de idéias, seja pelos sentimentos a eles direcionados. 
O estudo evidenciou que a dinâmica de estruturação do sistema está sendo balizada pelas eleições presidenciais, que desde o pleito de 1994 tem se concentrado em torno de duas organizações, PT e PSDB. Embora outros partidos tenham apresentado candidaturas no pleito presidencial, são essas duas agremiações que, além de controlarem as coligações nacionais mais efetivas eleitoralmente e as coalizões governamentais mais eficientes para a administração dos graves problemas econômicos e sociais do país, também têm sido responsáveis pela emergência de um padrão de disputa cada vez mais estável (BRAGA, 2010; LIMONGI \& CORTEZ, 2010). A estabilização da competição partidária no sentido de favorecer algum grau de previsibilidade no que se refere aos principais contendores, e sobre os resultados relacionados a seus apoios anteriores, é crucial em jovens democracias, como a brasileira, porque maiores serão as chances dos eleitores estabelecerem imagens partidárias e construírem lealdades (KINZO, 2007).

Nesse sentido, demonstramos que mesmo que os partidos de fato não estejam internalizados em termos de identidade partidária, ao menos no que concerne à estruturação do voto para presidente há uma divisão do eleitorado entre as duas principais organizações políticas em termos de simpatia partidária. A aferição da intensidade da simpatia ou afinidade partidária, enquanto heurísticas afetivas dos eleitores na decisão do voto nos permitiu verificar o quanto os partidos impactaram no comportamento dos eleitores nas eleições presidenciais de 2002, 2006 e 2010, e estão estruturando as escolhas eleitorais no país. Notamos que enquanto o PT e o PSDB ganharam maior importância em termos de simpatia no pleito de 2010 em relação às eleições de 2002 e, principalmente, 2006 outros partidos vem perdendo drasticamente a simpatia do eleitor de um pleito para outro.

Constatamos, especialmente, que em todas essas eleições examinadas, as simpatias eleitorais pelo PT e PSDB se mostraram um dos principais componentes de explicação do voto nos seus candidatos. Acompanhando grande parte da literatura sobre partidarismo no Brasil, a identificação partidária de parte do eleitorado com o PT, mais do que a simpatia por esse partido, alcançou os mais altos valores entre os partidos brasileiros. O estudo também apontou o consistente aumento nos índices de regressão para a simpatia pelo PSDB.

Ademais, apesar das simpatias partidárias serem uma heurística utilizada para decisão do voto entre os eleitores com maior escolaridade, foi observado que mesmo entre os menos escolarizados esse elemento foi fundamental para explicar o voto, demonstrando que mesmo entre eleitores com menor conhecimento político, os partidos, especialmente PT, PSDB e PMDB, têm balizado a decisão do voto.

Por fim, os modelos apontaram para uma crescente capacidade da simpatia pelo PT e PSDB polarizar o eleitorado, tornando essa variável fundamental para se 
BRAGA, M. S. S. e PIMENTEL, J. Jr. Os partidos políticos brasileiros realmente não...

entender o comportamento dos eleitores e para explicar o resultado final dos pleitos, em detrimento de outras variáveis explicativas do voto apontadas pela maioria da literatura. Entre essas variáveis estão as relacionadas ao perfil socioeconômico do eleitor, cuja capacidade explicativa foi diminuindo ao longo dos pleitos examinados.

\section{Referências Bibliográficas}

ANGEL, A. "Party Change in Chile in Comparative Perspective". Revista de Ciência Política. Santiago, vol.23, n², p-88-108, 2003.

ALMEIDA, A. C. A cabeça do eleitor. 3 ed: Rio de Janeiro: Record, 2008.

BALBACHEVSKY, E. "Identidade Partidária e Instituições Políticas no Brasil”. Lua Nova, n²6, 1992.

BOHN. S. "Social Policy and vote in Brazil Bolsa Família and the Shifts in Lula's Electoral Base". Latin American Research Review, vol.46, n 1, 2011.

BRADY, E. e SNIDERMAN, P. (1991). The likability heuristics. In: Sniderman, P. M; Brody, R. A. and Tetlock P. E (orgs.). Reasoning and Choice: Explorations in Political Psychology. New York, NY: Cambridge University Press, 1991.

BRAGA, M.S.S. “Eleições e Democracia no Brasil: a caminho de partidos e sistema partidário institucionalizados". Revista Brasileira de Ciência Política, vol. 4, p. 43-73, 2010.

CAMPBELL, A., CONVERSE, P. E, MILLER, W. E. e STOKES, D. The American Voter. New York: Wiley Press, 1960.

CARREIRÃO, Y. S. A decisão do voto nas eleições presidenciais brasileiras. Florianópolis: Editora da UFSC/FGV, 2002.

"Identificação ideológica, partidos e voto na eleição presidencial de 2006". Opinião

Pública, Campinas, vol. 13, nº 2, p.307-339, 2007. 
. "Opiniões políticas e sentimentos partidários dos eleitores brasileiros". Opinião Pública, Campinas, vol.14, p.319-351, 2008.

CARREIRÃO, Y. S. \& KINZO, M. D. "Partidos políticos, preferência partidária e decisão eleitoral no Brasil (1989-2002)". Dados, vol.47, n 1, 2004.

CARREIRÃO, Y. S. \& BARBETTA, P. "A eleição presidencial de 2002: a decisão do voto na região da grande São Paulo". Revista Brasileira de Ciências Sociais, Bauru, - SP, vol. 19, n 56, p.75-93, 2004.

CASTRO, M. M. M. de. Determinantes do comportamento eleitoral: A centralidade da sofisticação política. Tese de Doutorado, Rio de Janeiro, IUPERJ, 1994.

DALTON, R.J.; FLANAGAN, S. e BECK, P. A. Electoral Change in Advanced Industrial Democracies: Realignment or Dealignment? Princeton: Princeton University Press, 1984.

DALTON, R.J. \& WATTENBERG, M. (eds.). Parties Without Partisans - Political Changes in Advanced Industrial Democracies Oxford: Oxford University Press, 2000.

DALTON, R.J.; MACLISTER, I. \& WATTENBERG, M. P. "Democracia e identificação partidária nas sociedades industriais avançadas”. Análise Social, vol. XXXVIII, Lisboa, 2003.

DALTON, R.J. \& WELDON. "Partisanship and party system institutionalization". Party Politics vol.13, n², p.179-96, 2007.

DIAMOND, L. \& GUNTHER, R. Political Parties and Democracy. The Johns Hopkins University Press, 2001.

DIAS, M. R. "Projeção da imagem partidária nas estratégias de campanha na televisão: uma análise do HGPE 2002". Dados, Rio de Janeiro, vol. 48, n 1, p.147-183, 2005.

Under the mists of HPGE: Partisan Image in the Brazilian Presidential Campaigns (1989-2010). Paper presented at the Centre for Brazilian Studies. University of Oxford, 25 May 2011.

DOWNS, A. Uma teoria econômica da democracia. São Paulo: EDUSP, 1999 
FERNANDES, H. C. Voto e Gênero: O comportamento eleitoral feminino na sucessão presidencial de 2002. Dissertação de Mestrado. Departamento de Ciências Políticas, Universidade de São Paulo, 2006.

GUNTHER, R. et al, Political Parties: Old Concepts and New Challenges. Oxford University Press, 2002.

GUNTHER, R.; MONTERO, J. R. \& LINZ, J. Political Parties, Old Concepts and New Challenges, Oxford University Press, 2001.

HOLZHACKER D.O. \& BALBACHEVSKY, E. "Classe, ideologia e política: uma interpretação dos resultados das eleições de 2002 e 2006". Opinião Pública, Campinas, vol. 13, n 2, p.283. 306, 2007.

HUNTINGTON, S. A terceira onda: a democratização no final do século XX. São Paulo: Editora Ática, 1994.

KINZO, M. D. "Os partidos no eleitorado: percepções públicas e laços partidários no Brasil”. Revista Brasileira de Ciências Sociais, vol. 20, n 57, 2005.

KINZO, M. D. \& BRAGA, M.S.S. (orgs.). Eleitores e representação partidária no Brasil. São Paulo: Humanitas, 2007.

LAU, R. e REDLASWK, D. How Voters Decide. [Information Processing during Election Campaigns]. New York: Cambridge University Press, 2006.

LAVAREDA, A. A democracia nas urnas. Rio de Janeiro: Ed. Revan, 2ª edição, 1999.

LEVITIN, T. \& MILLER, W. "Ideological interpretations of presidential elections". American Political Science Review, vol. 73, n³, Set., 1979.

LINZ, J. Parties in Contemporary Democracies: Problems and Paradoxes. In: GUNTHER, R.; MONTERO, J. R. \& LINZ, J. Political Parties, Old Concepts and New Challenges, Oxford University Press, 2002.

LIMONGI, F. e CORTEZ, R. "As eleições de 2010 e o quadro partidário". Novos Estudos CEBRAP, $\mathrm{n}^{\circ} 88, \mathrm{p} .21 \cdot 37,2010$. 
MAINWARING, S. e SCULLY, T. Building Democratic Institutions: Party Systems in Latin America. Stanford: Stanford University Press, 1995.

MARTINS J.R, J. P. "Modelo sciológico de decisão de voto presidencial no Brasil - 1994. 2006". Revista Debates (UFRGS), vol. 3, p. 68-96, 2009.

Os partidos políticos nas eleições presidenciais brasileiras - $1994-2006$. In: $7^{\circ}$ encontro da ABCP. Recife, 2010.

MACKUEN, M. \& RABINOWITZ, G. Electoral Democracy. The University of Michigan Press, 2003.

MENEGUELLO, R. Partidos e tendências de comportamento: o cenário político em 1994, In: DAGNINO, E. (org.). Anos 90. Sociedade e Política no Brasil. São Paulo: Brasiliense, 1994.

Tendências eleitorais ao fim de 21 anos de democracia. In: MELO, C. R. \& SÁEZ, M. A. (orgs). A Democracia Brasileira. Balanço e perspectivas para o século 21. Belo Horizonte: Editora UFMG, 2007.

MOISÉS, J. A. "Democratização e cultura política de massas no Brasil”. Lua Nova, vol.26, n 26, p. 5-51, 1992.

MILLER, A. \& KLOBUCAR. T. The development of Party Identification in Post-Soviet Societies. American Journal of Political Science, vol.44, $\mathrm{n}^{\circ} 4,2000$.

PAIVA, D., BRAGA,M.S.S. e PIMENTEL Jr. J. "Eleitorado e partidos políticos no Brasil". Opinião Pública. Campinas, vol. 13, n² 2, p.388-408, 2007.

PIMENTEL JR., J. Laços Afetivos e partidos políticos. In: BRAGA, M. S. S. (Org.).

KINZO, M. D. G. (org.). Eleitores e representação partidária no Brasil. 1. ed. São Paulo: Humanitas, 2004.

SAMUELS, D. "As bases do petismo". Opinião Pública, Campinas, vol.10, n² 2, p.221-241, 2004.

SAMUELS, D. e ZUCCO, C. The Roots of Petismo, 1989-2010. In: 2010 Meeting of the American Political Science Association (Apsa), Washington. p. 1·34, 2010. 
SANTOS, W. G. dos. "As Eleições e a Dinâmica do Processo Político Brasileiro". Dados, Rio de Janeiro, IUPERJ, 21, 1978.

SAEZ, M. A. \& FRIDEINBERG, F. "Partidos Políticos na América Latina", Opinião Pública, Campinas, vol. 8, $n^{\circ} 2$, p.137-157, 2002.

SINGER, A. Collor na periferia: A volta por cima do populismo?. In: LAMOUNIER, B. (org.). De Geisel a Collor: O balanço da transição. São Paulo, Sumaré, 1990.

Esquerda e direita no eleitorado brasileiro, São Paulo: EDUSP, 1999.

. "Raízes sociais e ideológicas do Lulismo". Novos Estudos CEBRAP, São Paulo, n 85, p. 83.102, nov. 2009.

. "A segunda alma do partido dos trabalhadores". Novos Estudos CEBRAP, São Paulo, n 88, dez. 2010.

WATTENBERG, M. "Party Identification and Party Images: A comparison of Britain, Canada, Australia and United States". Comparative Politics, vol.15, $\mathrm{n}^{\circ}$ 1, 1982.

WEBB, P. Political Parties in Britain: Secular Decline or Adaptive Resilience? In: Political Parties in Advanced Industrial Democracies, Oxford University Press, 2002.

VEIGA,L. "Os partidos brasileiros na perspectiva dos eleitores; mudanças e continuidades na identificação partidária e na avaliação das principais legendas após 2002". Opinião Pública, Campinas, vol. 13, n² 2, p.340-365, 2007.

Maria do Socorro Sousa Braga - mssbraga@uol.com.br Jairo Pimentel Jr - jairopimentel@usp.br

Recebido para publicação em setembro de 2011. Aprovado para publicação em outubro de 2011. 